\title{
ОБЩЕСТВЕННОЕ СОЗНАНИЕ КРЕСТЬЯН В ПЕРИОД КОЛЛЕКТИВИЗАЦИИ СЕЛЬСКОГО ХОЗЯЙСТВА
}

\section{PEASANTS PUBLIC CONSCIOUSNESS DURING THE COLLECTIVIZATION OF AGRICULTURE}

\author{
I. Bondar \\ E. Malyshkina \\ M. Dahrendorf
}

Summary: The article attempts to identify the features of agricultural collectivization in the Kuban, Don, Stavropol and some other Slavic districts of the North Caucasus. The reorganization of the regional agrarian sector and the enlargement of newly created farms through the union of small collective farms and artels are traced. The central place is devoted to the question of rural everyday life, which was a clear reflection of the peasant community age-old traditions of life organizing.

Keywords: agricultural sector, collective farm, agricultural reform, the peasants, collectivization.
Бондарь Ирина Алексеевна

Д.и.н., дочент, Филиал ГБОУ ВО «Ставропольский государственный педагогический институт» в г. Ессентуки

Sloikin89@rambler.ru

Малышкина Елена Владимировна

К.и.н., доцент, Институт сервиса, туризма и дизайна (филиал) Северо-Кавказского федерального университета в г. Пятигорске soft_25@mail.ru

Дарендорф Марианна Викторовна К.и.н., Филиал ГБОУ ВО «Ставропольский государственный педагогический институт» в г. Ессентуки history-yesspi@mail.ru

Аннотация: В статье предпринята попытка выявить особенности коллективизации сельского хозяйства в Кубанском, Донском, Ставропольском и некоторых других славянских округах Северного Кавказа. Прослеживается реорганизация краевого аграрного сектора, укрупнения вновь созданных хозяйств посредством объединения мелких колхозов и артелей. Центральное место занимает вопрос сельской повседневности, которая являлась наглядным отражением вековых традиций организации жизнедеятельности крестьянского сообщества.

Ключевые слова: аграрный сектор, колхоз, реформирование сельского хозяйства, крестьяне, коллективизация.

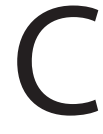

оздание крупных колхозов являлось одной из особенностей коллективизации сельского хозяйства в Кубанском, Донском, Ставропольском и некоторых других славянских округах Северо-Кавказского края. Даже после того, как основные мероприятия в сфере колхозного строительства в крае вступили в стадию завершения, началась реорганизация краевого аграрного сектора на предмет укрупнения вновь созданных хозяйств посредством объединения мелких колхозов и артелей. Центральное и краевое руководство исходило из того, что крупные колхозные хозяйства смогут быстрее наладить производство и добиться высоких показателей. Однако они не учли при этом слабую материально-техническую оснащенность аграрной отрасли, которая отнюдь не способствовала эффективной работе колхозов-гигантов. Из-за недостатка спецтехники приходилось составлять графики ее использования на различных производственных участках, что в итоге привело к необходимости дробления крупных хозяйств на мелкие колхозы. Только после решения вопросов технической оснащенности сельского хозяйства к концу 1931 года в отрасли вновь стали появляться колхозные объединения. Но даже в это время колхозный строй все еще находился на этапе становления, поскольку около $20 \%$ крестьянских хозяйств продолжали заниматься индивидуальным производством агарной продукции. Это соотношение между коллективными и индивидуальными производителями не устраивало политическую власть, но вполне удовлетворяло ее хозяйственно-экономические потребности и соответствовало возможностям дальнейшего реформирования сельского хозяйства [7, л. 2].

Что касается крестьянского населения, то статистические параметры реформ его не волновали. Крестьяне, смирившись с утратой хозяйственной самостоятельности, все больше задумывались о дальнейшей жизни в коллективизированном селе, о том, какое место им будет отведено в структуре общественных отношений. В социальной памяти каждого сельского жителя еще свежи были воспоминания о прошлых временах, когда жизнь была не менее сложной, но ее наполняли привычные традиции и ценности, передававшиеся из поколения в поколение. При советской власти традиционный уклад жизни претерпел значительные изменения и в ней появились новые, до сих пор неведанные элементы. Сначала они воспринимались настороженно и даже агрессивно, но потом крестьяне начали постепенно при- 
выкать и приспосабливаться к изменениям в хозяйстве и быту. Это касается, в том числе и отношения к колхозам. Со временем крестьяне стали понимать бессмысленность противодействия коллективизации и писать заявления о готовности к обобществлению имущества не по убеждению, а из безысходности сложившегося положения. Противостояние с властью ничего хорошего не сулило. Однако, вступив в колхоз, они решали текущую проблему, а будущее все еще оставалось неведомым и таинственным. Ощущение неизвестности удручало и заинтересовывало одновременно большинство сельских жителей. Спросить было не кого, посоветоваться не с кем, опыта реформ такого рода просто не существовало. В то же время неопределенность порождала многочисленные слухи и домыслы, которые нередко использовались противниками колхозного строительства в провокационных целях.

Несколько успокаивающе на общественное сознание крестьян действовал фактор постепенной стабилизации процесса обобществления, нарушений и злоупотреблений стало меньше. При описи имущества составлялись необходимые документы, заверенные подписями и печатями, что для крестьян являлось гарантией справедливости и соблюдения законности. Правда, они не всегда могли найти ответы на злободневные для них вопросы. Непонятен был, например, запрет на продажу продукции, произведенной на собственном участке с разрешения властей. Приусадебный участок всегда являлся средством пропитания крестьянской семьи и получения дополнительных доходов от реализации на рынке излишков продовольствия, теперь же возможность использования этого источника выживания не зависела от воли хозяина, а регламентировалась начальством. Крестьяне не могли также самостоятельно и осмысленно объяснить действия властей, направленные на ликвидацию традиций натурального обмена, который помогал им поддерживать необходимый уровень жизнеобеспечения. Они никак не могли осознать причины насильственного закрытия сельских и городских рынков, наивно ожидая появления вместо них новых механизмов и средств товарообмена [6, с. 147-149].

В своих мыслях крестьяне постоянно возвращались в прошлое и сравнивали его с настоящими временами. На основе только им одним известных критериев они делали вывод о том, что раньше жить было проще и понятней. Современность пугала не только высокими налогами, но и не решенными вопросами оплаты труда по трудодням. Попытки выяснить все тонкости новой аграрной политики через обращения в компетентные органы ни к чему не приводили, поэтому им казалось, что весь мир вокруг настроен против них. В таких условиях жизни и работы без видимых перспектив вполне естественным представляется обособленность от внешнего окружения, замкнутость в себе и собственных размышлениях.
Часть крестьянского населения края возлагала надежды на центральную власть. Через почтовые отделения различных населенных пунктов в Москву были направлены тысячи коллективных и индивидуальных письменных обращений по самым различным вопросам жизни в новых условиях. Однако большинство крестьянских писем в силу неведомых им причин оказывались у местных чиновников, которые давали неоднозначные ответы на поставленные вопросы, предупреждали, а иногда и прямо угрожали принять меры к авторам посланий, если они не откажутся от практики обращений в правительственные инстанции. Такие факты также озадачивали крестьян, поскольку они не считали себя виновными в совершении каких-то противоправных действий, а просто воспользовались данным им самой властью правом обращаться к ней по любым вопросам [5, c. 198].

Не осталась неизменной и сельская повседневность, которая, как известно, являлась наглядным отражением вековых традиций организации жизнедеятельности крестьянского сообщества. Опять же из своей прошлой жизни крестьяне знали, что иной бедняк был способен устроить свой быт намного комфортней и интересней, чем самый удачливый и обеспеченный хозяин. При всех внешних различиях крестьянского жилища именно быт являлся той самой сферой, которая отличала крестьянина от представителей других сословий. Несомненно, зажиточные крестьяне имели потенциальные возможности вести достойный их доходам образ жизни, однако, чаще всего эти возможности оставались невостребованными [1, с. 174]. За хозяйственными заботами и трудовыми буднями для их реализации не оставалось времени. Конечно, были и такие крестьяне, для которых благополучная бытовая сторона жизни являлась самоцелью, но они исповедовали другие ценности и не составляли большинство сельского населения. Речь идет, в первую очередь, о так называемых отходниках, выезжавших на заработки в города, занимавшихся выполнением строительных работ по найму и т.п. Возвращаясь домой, они привносили в сельскую повседневность элементы городской культуры и порой становились ее заложниками на всю жизнь. Но, в отличие от других односельчан, они не были обременены хозяйственными заботами, поэтому могли позволить себе бытовое благополучие.

Если взять, например, типичный дом крестьянина славянских районов Северо-Кавказского края, то в основном эта была саманная хата с земляным полом и несколькими жилыми помещениями. В исследуемый период саман был самым распространенным и доступным строительным материалом и на Дону, и на Кубани, и на Ставрополье. Построенные из него дома покрывали соломенными или камышовыми крышами [3, л. 14]. Эти же материалы в селах и станицах использовались и для хозяйственных построек [2, л. 3]. 
Приведенные и многие другие примеры свидетельствуют о том, что зажиточность в сельской среде далеко не всегда являлась синонимом благополучия. К тому же свою роль играли и внутрисельские традиции, которые не подпадали под влияние хозяйственной предпри- имчивости. Нужно заметить, что коллективизация не сильно отразилась на крестьянском быте. Изменения коснулись, в первую очередь, сферы взаимоотношений между представителями различных поколений сельского общества.

\section{ЛИТЕРАТУРА}

1. Бежкович А.С. и др. Хозяйство и быт русских крестьян. Памятники материальной культуры. - М.: Советская Россия, 1959. - 329 с.

2. Государственный архив Ставропольского края (ГАСК). Ф. 127. Оп. 1. Д. 7. Л. 3.

3. ГАСК. Ф. 806. 0п. 1. Д. 410. Л. 14.

4. Крестьянские представления о социализме в письмах 20-х гг. // Неизвестная Россия. XX век. Архивы. Письма. Мемуары / сост. В.А. Козлов, С.В. Завьялов. В 4-х т. Т. 3. - М.: Историческое наследие, 1993. - 416 с.

5. Литвак К.Б. Жизнь крестьянина 20-х годов: современные мифы и исторические реалии // НЭП: приобретения и потери: сборник статей / Р.У. Дэвис; Ин-т российской истории РАН. - М.: Наука, 1994. - С. 199-202. - 217 с.

6. Малафеев А.Н. История ценообразования в СССР (1917-1963 гг.). - М.: Мысль, 1964. - 439 с.

7. Российский государственный архив экономики (РГАЭ). Ф. 7446. 0п. 1. Д. 225. Л. 2.

๑ Бондарь Ирина Алексеевна (Sloikin89@rambler.ru), Малышкина Елена Владимировна (soft_25@mail.ru),

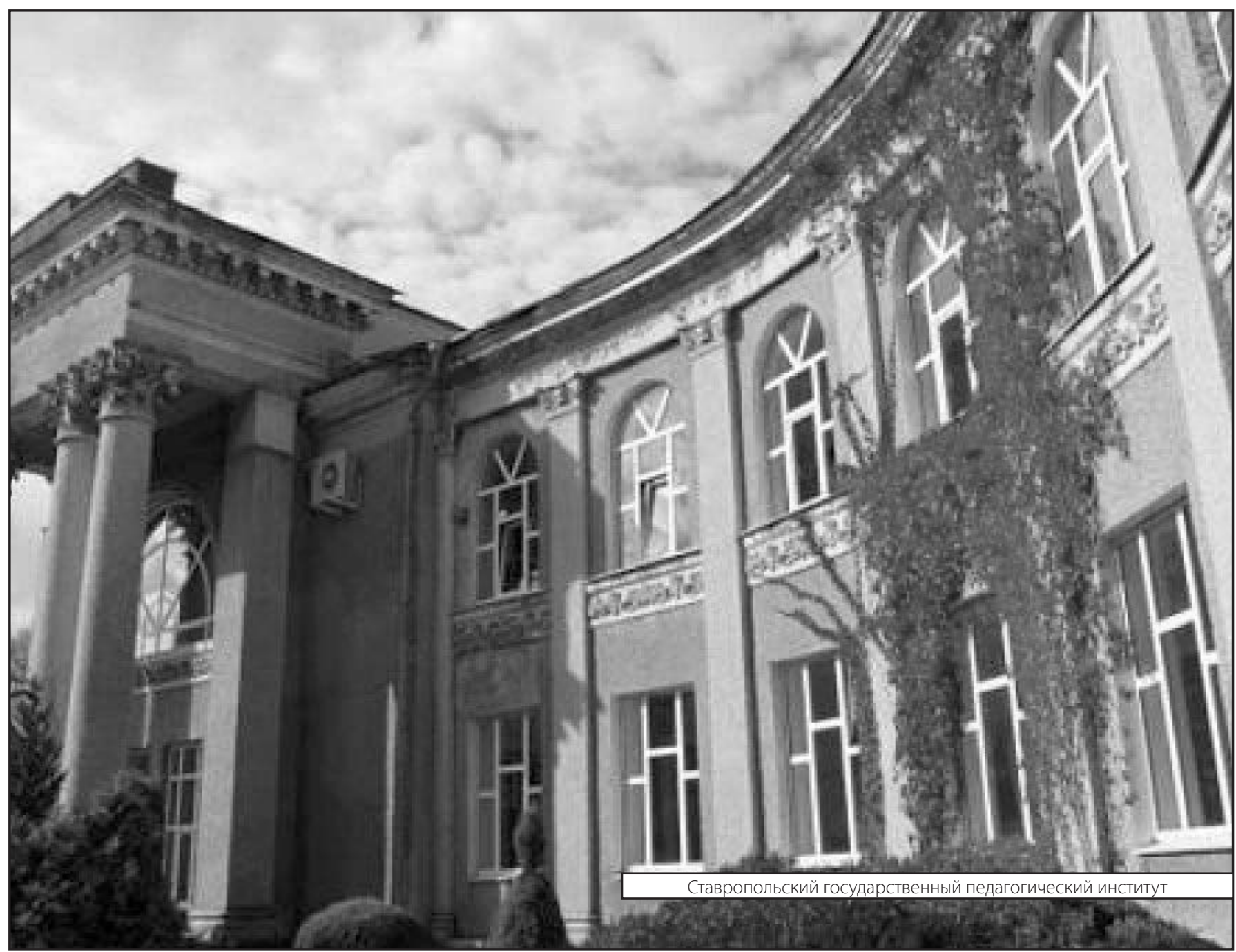

